\title{
Evaluasi Mutasai Jabatan Anggota Kepolisian Menggunakan Metode Profile Matching dan Multi Attribute Utility Theory
}

\author{
Chairun Nas ${ }^{1}$, Sarjon Defit ${ }^{2}$, Julius Santoni ${ }^{3}$ \\ 1,2,3 Magister Komputer, Fakultas Ilmu Komputer, Universitas Putra Indonesia YPTK Padang \\ Jl. Raya Lubuk Begalung Nan XX, Padang, 25145 \\ Email: chairunnasrpl@gmail.com, sarjonde@yahoo.co.uk, juliussantony@yahoo.co.id
}

\begin{abstract}
ABSTRAK
Mutasi jabatan bertujuan untuk menunjang operasional dan meningkatkan efektifitas kerja dari institusi kepolisian. Tujuan dari penelitian ini membantu dalam pengambilan keputusan untuk mutasi jabatan dengan mengevaluasi nilai kriteria setiap anggota kepolisian. Dalam penelitian ini dilakukan pengolahan data kriteria penilaian dan data personel kepolisian yang diperoleh melalui hasil wawancara bersama kepala bagian sumber daya serta pengisian quisioner oleh 15 anggota kepolisian. Dari data tersebut dilakukan pengujian dengan menggunakan metode Profile Matching dan Multi Atribute Utility Theory. Hasil dari pengujian metode-metode tersebut adalah dihasilkan sebuah keputusan pada sebuah alternatif dengan nilai total sebesar 83,3\%. Maka metode ini dibutuhkan untuk mengevaluasi penentuan mutasi jabatan sehingga menghasilkan keputusan terbaik.
\end{abstract}

Kata Kunci: Keputusan, Mutasi, Profile Matching, Multi Atribute Utility Theory, Evaluasi

\section{ABSTRACT}

Position mutation aims to support operations and improve the effectiveness of work from the police institution. The purpose of this research is to assist in decision making for transfer positions by evaluating the criteria for each member of the police. In this study, data processing criteria and police personnel data were obtained through interviews with the head of the resource department and the quisioning by 15 police officers. From these data, testing is done using the Profile Matching method and the Multi Attribute Utility Theory. The results of testing these methods are produced a decision on an alternative with a total value of $83.3 \%$. So this method is needed to evaluate the determination of position mutations so as to produce the best decisions.

Keywords: Decission, Mutation, Profile Matching, Multi Atribute Utility Theory, Evaluation

Corresponding Author:

Chairun Nas

Magister Komputer, Fakultas Ilmu Komputer

Universitas Putra Indonesia YPTK Padang

Email: chairunnasrpl@gmail.com

\section{Pendahuluan}

Mutasi jabatan merupakan sebuah tindakan yang dilakukan untuk memindahkan karyawan ke posisi baru, guna menjamin kelancaran dalam kegiatan organisasi. Dengan mutasi jabatan, maka setiap kegiatan dalam organisasi dapat berjalan dengan baik. Dalam proses mutasi jabatan sering kali berpedoman kepada perkiraan dan permintaan yang mengakibatkan tidak efisiennya jabatan yang diemban anggota dan proses penentuan memakan waktu yang lama. Faktor ketidakmampuan pemimpin dalam mengembangkan standar kebijakan atau keputusan yang baik, protokol, lingkungan dan keterampilan yang optimal bagi organisasi menyebabkan menurunnya kegiatan [1]. Hal ini menjadi permasalahan yang terjadi pada pihak kepolisian. Tidak adanya sistem pengelolaan yang baik menjadi penghambat dalam penentuan mutasi jabatan

Dalam mengatasi persoalan tersebut, dibutuhkan sebuah sistem pengambilan keputusan yang mampu mengkombinasikan model atau metode perhitungan matematika dalam proses pengambilan keputusan penentuan mutasi jabatan. Dalam sistem pengambilan keputusan, pengolahan data dilakukan dengan pengurutan / peringkat menggunakan algoritma dasar atau metode yang sering diperlukan dalam mengambil solusi [2]. Maka metode yang tepat untuk menganalisis nilai profile setiap alternatif dan melakukan perangkingan terhadap alternatif tersebut dalam mutasi jabatan digunakanlah metode Profile Matching dan Multi Atribute Utility Theory (MAUT).

Metode Profile Matching membandingkan nilai profile yang akan dinilai dengan nilai ideal yang di 
tetapkan. Hasil akhir dari penelitian ini adalah nilai kompetensi tertinggi merupakan hasil keputusan dari pada metode Profile Matching [3]. Metode MAUT mengolah kriteria penilaian berdasarkan fungsi utilitas setiap alternatif. Fungsi utilitas ditentukan oleh banyaknya karakteristik terbaik dan nilai-nilai pada kasus terburuk dari setiap atribute [4]. Maka dengan menggunakan metode tersebut, dapat dihasilkan nilai evaluasi yang dapat dijadikan saran keputusan dalam penentuan mutasi jabatan.

Pada penelitian tentang mutasi jabatan sebelumnya, sistem pengambilan keputusan penentuan mutasi jabatan diimplementasikan dengan menggunakan proses perhitungan metode Multifactor Evaluation Process (MEP). Dalam proses perhitungan metode MPE, nilai dari setiap alternatif dikalikan dengan nilai bobot masing-masing kriteria, sehingga menghasilkan nilai bobot evaluasi. Hasil akhir dari penelitian ini adalah alternatif yang memiliki nilai bobot evaluasi tertinggi yang menjadi saran keputusan terbaik [5]. Namun dalam penelitian ini ditemukan kekurangan pada hasil keputusan yang disebabkan nilai alternative tidak dilakukan proses normalisasi, sehingga hasil yang didapat tidak maksimal.

Penelitian dengan menggunakan metode Profile Matching telah diimplementasikan terhadap penentuan karyawan terbaik. Pada penelitian ini, ditentukan kriteria penilaian seperti perfoma kerja, sikap, teamwork dan kapasitas intelektual. Dengan membandingkan faktor penilaian kriteria setiap alternatif dengan nilai ideal yang telah ditetapkan, maka didapatkan nilai kompetensi. Selanjutnya ditentukan Core Factor dan Second Factor dari setiap nilai kompetensi sehingga menghasilkan nilai total tertinggi. Dari total nilai, diperoleh nilai tertinggi 4,6362 pada sebuah alternatif yang dijadikan sebuah saran dalam keputusan [3].

Pada penelitian untuk penentuan mutasi jabatan karyawan, dilakukan implementasikan metode Profile Matching dan Promethee. Dengan mencari nilai bobot untuk setiap atribut atau aspek penilaian pada metode Profile Matching, dihasilkan nilai akhir yang dioptimalkan dengan menggunakan metode Promethee. Dengan menggunakan metode tersebut, maka dapat dihasilkan perangkingan karyawan yang cocok untuk memenuhi posisi jabatan tersebut [6].

Penelitian sebelumnya metode MAUT telah diimplementasikan dalam penentuan perencanaan dan pemeliharaan jembatan. Setiap alternatif memiliki nilai utilitas pada masing-masing kriterianya. Nilai utilitas akan dilakukan normalisasi sehingga menghasilkan nilai evaluasi. Dari nilai evaluasi yang diperoleh, didapatkan akurasi hasil sebesar $70 \%$, sehingga nilai evaluasi dari setiap alternatif dapat diambil sebagai keputusan [7].

Selain dari itu metode MAUT juga telah diimplementasikan pada seleksi penerimaan karyawan. Dengan melakukan pengolahan terhadap nilai ujian calon karyawan berdasarkan variabel-variabel penilaian yang telah ditetapkan, maka dihasilkan nilai akhir yang diurutkan berdasarkan rangking tertinggi. Dengan menggunakan metode MAUT, maka telah dapat menganalisa calon karyawan yang lulus atau tidak [8].
Pada penelitian metode MAUT dan Vooting Copeland Score (VCS) dilakukan untuk menyeleksi pemilihan debitur yang menunggak pembayaran cicialn dan layak untuk dilakukan restrukrisasi. Setiap alternatif diberikan nilai kepuasan terhadap kriterianya dan diuji dengan menggunakan metode MAUT. Hasil dari metode MAUT akan dilakukan perangkingan dan diakomodir dengan menggunakan metode VCS untuk menentukan kemenangan dan kekalahan setiap alternatif. Maka dengan menggunakan metode tersebut dapat dihasilkan debitur-debitur yang layak untuk di restrukrisasi [9].

Dari penelitian sebelumnya yang telah dibahas, metode Profile Matching menghasilkan keputusan berdasarkan profile yang ideal, sedangkan metode MAUT menghasilkan nilai evaluasi dari nilai kepuasan. Maka kedua metode ini dapat dikolaborasikan untuk mendapatkan hasil keputusan yang lebih optimal dalam penentuan mutasi jabatan.

\section{Tinjauan Pustaka}

\section{Sistem Pendukung Keputusan}

Keputusan adalah suatu kegiatan memilih sebuah strategi atau tindakan dalam pemecahan masalah [9]. Dalam pengambilan keputusan, pengolahan data dan informasi perlu dilakukan yang bertujuan untuk menghasilkan alternatif keputusan yang dapat diambil [10]. Maka Pengambilan keputusan mesti didasarkan kepada pertimbangan-pertimbangan logis sehingga dapat diterima oleh semua pihak yang menjadi sasaran keputusan tersebut [11]. Untuk itu dibutuhkan sebuah sistem yang dapat membantu menghasilkan keputusan.

Sistem pengambilan keputusan merupakan suatu sistem interaktif berbasis komputer yang ditujukan untuk membantu dalam pembuatan keputusan dengan memanfaatkan data dan model untuk menyelesaikan suatu masalah yang bersifat tidak terstruktur [10]. Pada dasarnya sistem pengambilan keputusan dirancang untuk mendukung seluruh tahapan pengambilan keputusan mulai dari mengidentifikasi masalah, memilih data yang relevan, menentukan pendekatan yang digunakan dalam proses pengambilan keputusan, sampai mengevaluasi pemilihan alternatif [12].

\section{Metode Profile Matching}

Metode Profile Matching merupakan mekanisme pengambilan keputusan yang mengasumsikan bahwa ada tingkat ideal sebuah variabel prediktor yang harus dipenuhi oleh subjek yang bukan tingkat minimal yang harus dipenuhi atau dilewati [13]. Metode Profile Matching membandingkan nilai data aktual dari profil yang dinilai dengan nilai profil yang diharapkan sehinggan menghasilkan perbedaan kompetensi [3]. Dengan metode tersebut, pengambil keputusan dapat menentukan standar kompetensi dalam keputusannya.

\section{Metode Multi Atribute Utility Theory (MAUT)}

Metode MAUT adalah teori utilitas (nilai kepuasan) yang dapat menentukan tindakan terbaik 
dalam pemecahan masalah dengan menetapkan utilitas untuk setiap alternatif yang mungkin terjadi dan menghitung kemungkinan utilitas terbaik [14]. Teori utilitas mengevaluasi nilai akhir $\mathrm{v}(\mathrm{x})$ dari suatu objek $\mathrm{x}$ didefenisikan sebagai bobot yang dijumlahkan dengan suatu nilai yang relevan terhadap nilai dimensinya [8]. Dengan menggunakan metode MAUT, dihasilkan urutan peringkat dari evaluasi alternatif.

\section{Metode Penelitian}

Dalam penelitian ini, dapat diuraikan tahapan proses pengambilan keputusan dengan menggunakan metode-metode yang digunakan pada Gambar 1.

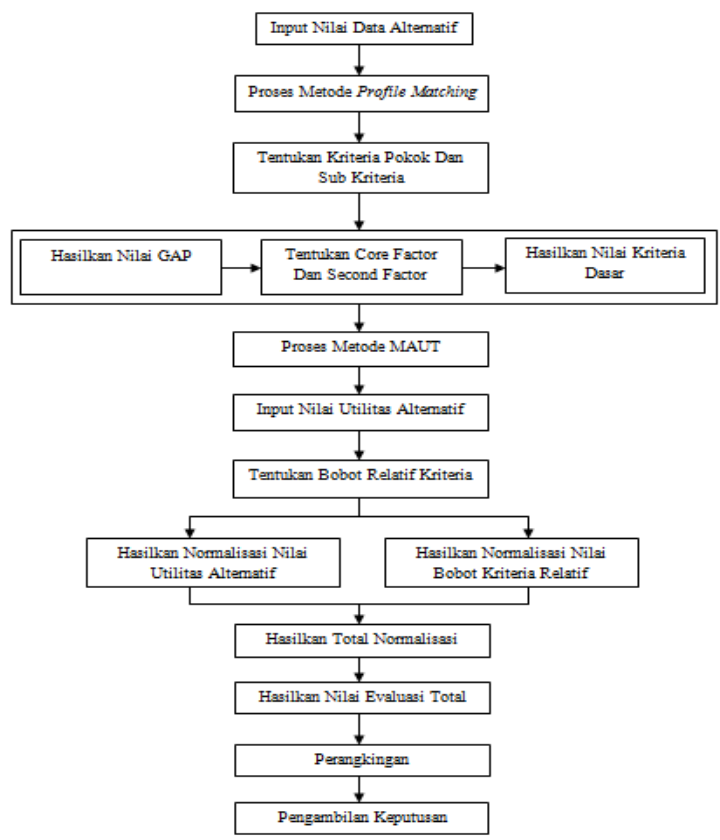

Gambar 1. Tahapan Proses Penelitian

Pada Gambar 1 menjelaskan tahapan dari sistem pengambilan keputusan untuk penentuan mutasi jabatan anggota kepolisian dengan menggunakan metode Profile Matching dan MAUT.

\section{Input Nilai Data Alternatif}

Data yang digunakan dalam penelitian ini adalah data personel kepolisian yang dijadikan sebagai alternatif. Adapun data tersebut dapat dilihat pada Tabel 4

\section{Kriteria Pokok dan Sub Kriteria}

Nilai pada alternatif ditentukan berdasarkan kriteria penilaian untuk mutasi jabatan. Kriteria yang digunakan untuk proses metode Profile Matching adalah kriteria penilaian standar seperti Tabel 1:

Tabel 1. Tabel Kriteria Penilaian Standar

\begin{tabular}{lclc}
\hline Kode & Nama & Sub Kriteria & Bobot \\
\hline \multirow{4}{*}{ C01 } & & Bripda / Briptu & 1 \\
& Pangkat & Brigadir / Bripka & 2 \\
& & Aipda / Aiptu & 3 \\
& & Ipda / Iptu & 4 \\
\hline \multirow{4}{*}{ C02 } & Jabatan & Anggota Unit / Banit & 1 \\
& Personel & Paur Min / Bamin & 2 \\
& & Kasubnit & 3 \\
& & Kanit / KBO & 4 \\
\hline \multirow{4}{*}{ C03 } & Lama Masa & 13 s/d 12 Tahun & 1 \\
& Dinas & 19 s/d 24 Tahun & 2 \\
& & >=25 Tahun & 3 \\
C04 & Pengalaman & Tidak Berpengalaman & 4 \\
& Fungsi & Kurang Berpengalaman & 1 \\
& Terkait & Berpengalaman & 3 \\
\hline \multirow{3}{*}{ C05 } & Pelatihan & Belum Pernah & 1 \\
& Fungsi & 1 s/d 2 Kali & 2 \\
& Terkait & >=3 Kali & 3 \\
\hline
\end{tabular}

Kriteria penilaian standar akan diolah dengan menggunakan metode Profile Matching sehingga menghasilkan nilai kriteria dasar yang akan diolah dengan menggunakan metode MAUT.

\section{Nilai GAP}

Nilai GAP atau nilai kompetensi diperoleh dari selisih nilai profil dengan nilai scoring/standar. Untuk menentukan nilai GAP personel dapat menggunakan rumus:

$$
G A P=\text { Nilai Alternatif }- \text { Nilai Scoring }
$$

Setelah mendapatkan nilai selisih GAP, selanjutnya dapat ditentukan nilai Perbandingan GAP dengan melihat pada Tabel 2.

Tabel 2. Tabel Perbandingan GAP

\begin{tabular}{ccc}
\hline $\begin{array}{c}\text { Selisih } \\
\text { GAP }\end{array}$ & $\begin{array}{c}\text { Nilai } \\
\text { Perbandingan }\end{array}$ & Keterangan \\
\hline 0 & 5 & Tidak Ada Perbedaan \\
1 & 4,5 & Lebih Dari 1 \\
-1 & 4 & Kurang Dari 1 \\
2 & 3,5 & Lebih Dari 2 \\
-2 & 3 & Kurang Dari 2 \\
3 & 2,5 & Lebih Dari 3 \\
$\mathrm{N}$ & n.. & Seterusnya \\
\hline
\end{tabular}

\section{Nilai Core Factor dan Second Factor}

Setelah mendapatkan nilai perbaandingan GAP, selanjutnya kelompokkan kriteria penilaian menjadi 2 kelompok, yaitu Core Factor dan Second Factor.

a. Core Factor $(\mathrm{CF})$

CF merupakan faktor utama dalam penilaian kriteria yang paling dibutuhkan. Kriteria yang akan menjadi faktor utama adalah :

1) Kriteria Pangkat Personek

2) Kriteria Jabatan 
3) Kriteria Lama Masa Dinas

Adapun rumus untuk menghitung CF adalah:

$N C F=\frac{\sum N C}{\sum I C}$

Dimana,

NCF : Nilai rata-rata faktor utama

NC : Jumlah total faktor utama

IC : Jumlah banyak faktor utama

b. Second Factor (SF)

SF merupakan faktor kedua atau faktor pendukung dalam penilaian kriteria.Kriteria yang akan menjadi faktor kedua adalah:

1) Kriteria Pengalaman Fungsi Terkait

2) Kriteria Pelatihan Fungsi Terkait

Adapun rumus untuk menghitung SF adalah :

$$
N S F=\frac{\sum N S}{\sum I S}
$$

Dimana,

NSF : Nilai rata-rata faktor kedua

NS : Jumlah total faktor kedua

IS : Jumlah banyak faktor kedua

\section{Nilai Kriteria Dasar}

Dari total perhitungan $\mathrm{CF}$ dan $\mathrm{SF}$, didapatkan nilai kriteria dasar. Untuk menghitung nilai kriteria dasar menggunakan rumus:

$N=(x) \% N C F+(X) \% N S F$

Dimana,

$\mathrm{N}$ : Total nilai kriteria dasar

NCF : Nilai rata-rata faktor utama

NSF : Nilai rata-rata faktor kedua

$(\mathrm{x}) \%$ : Persentase kepentingan

\section{Input Nilai Utilitas Alternatif}

Nilai utilitas adalah nilai kepuasaan sebuah kriteria dari alternatifnya. Kriteria yang digunakan adalah kriteria penilaian personel dan diproses menggunakan metode MAUT. Nilai utilitas alternatif dapat dilihat pada Tabel 10 .

\section{Bobot Relatif Kriteria}

Bobot relatif kriteria merupakan besarnya nilai atau seberapa penting kriteria tersebut dalam penentuan mutasi jabatan yang diukur dengan nilai persentase. Kriteria nilai personel dan bobot relatif dapat dilihat pada Tabel 3:

Tabel 3. Tabel Kriteria Nilai Personel

\begin{tabular}{ccc} 
Kode & Nama Kriteria & Bobot \\
\hline K01 & Nilai Kriteria Dasar & $50 \%$
\end{tabular}

\begin{tabular}{lll} 
K02 & Nilai Generik Pejabat Penilai & $10 \%$ \\
K03 & Nilai Generik Rekan Kerja & $10 \%$ \\
K04 & Nilai Spesifik & $20 \%$ \\
K05 & Nilai Psikotest & $10 \%$ \\
\hline
\end{tabular}

\section{Normalisasi Nilai Utilitas Alternatif dan Bobot Relatif Kriteria}

Normalisasi merupakan proses mengubah nilai dari alternatif kedalam skala 0 sampai 1. Rumus yang digunakan untuk normalisasi nilai utilitas alternatif adalah:

$$
\forall i(x)=\frac{x-x i(\min )}{x i(\max )-x i(\min )}
$$

Dimana,

Ui(x) : Nilai normaliasi utilitas setiap alternatif $\mathrm{x} \quad$ : Nilai utilitas kriteria dari setiap alternatif xi(min) : Nilai terendah dari utilitas setiap kriteria xi(max): Nilai tertinggi dari utilitas setiap kriteria

Untuk normalisasi bobot relatif kriteria, dapat digunakan rumus:

$$
W i=\frac{W i^{i}}{\sum W_{i}^{i}}
$$

Dimana,

Wi : Nilai normalisasi bobot relatif kriteria

Wi' : Tingkat kepentingan bobot kriteria

$\sum W^{\prime} \quad$ :Jumlah kepentingan bobot setiap kriteria

\section{Total Normalisasi}

Total normaliasi merupakan nilai perkalian antara nilai normaliasi alternatif dan nilai normalisasi kriterianya. Rumus yang digunakan adalah :

$$
\text { Total Normalisasi }=U i(x){ }^{*} W i
$$

Dimana,

Ui(x) : Nilai normaliasi utilitas setiap alternatif

Wi : Nilai normalisasi bobot relatif kriteria

\section{Nilai Evaluasi Total}

Nilai evaluasi total merupakan hasil akhir dari proses metode MAUT yang dapat dijadikan sebagai bahan pertimbangan dalam pengambilan keputusan. rumus untuk mencari nilai evaluasi total adalah :

$$
v(x)=\sum_{i=1}^{n}\left(\begin{array}{l}
n \\
k
\end{array}\right) \text { wi ui }(x)
$$

Dimana,

$\mathrm{v}(\mathrm{x})$ : Nilai Evaluasi total

wi : Nilai Normaliasi Bobot relatif kriteria 


$$
\begin{aligned}
& \text { vi(x) : Nilai normalisasi utilitas setiap alternatif } \\
& \mathrm{i} \quad \text { : Indeks untuk menunjukkan kriteria } \\
& \mathrm{n} \quad \text { : Jumlah kriteria }
\end{aligned}
$$

\section{Perangkingan}

Perangkingan dilakukan setelah hasil nilai evaluasi total diperoleh. Perangkingan mengurutkan nilai evaluasi total dari yang tertinggi ke yang terkecil.

\section{Pengambilan Keputusan}

Pengambilan keputusan dapat dilakukan dengan berpatokan kepada nilai evaluasi total. Nilai evaluasi total tertinggi dapat dijadikan saran keputusan terbaik untuk penentuan mutasi jabatan.

\section{Hasil dan Pembahasan}

Berdasarkan metodologi penelitian yang telah dibahas, sebelumnya, maka dapat dijelakan proses penentuan mutasi jabatan menggunakan metode Profile Matching dan MAUT. Data uji dapat dilihat pada Tabel 4:

Tabel 4. Tabel Data Personel

\begin{tabular}{ccc}
\hline No & NRP Personel & Nama Personel \\
\hline 1 & NRP001 & A \\
2 & NRP002 & B \\
3 & NRP003 & C \\
4 & NRP004 & D \\
\hline
\end{tabular}

Dari data uji tersebut, dimasukkan nilai kriteria setiap alternatif berdasarkan nilai bobot sub kriterianya. Nilai kriteria setiap alternatif dapat dilihat pada Tabel 5 :

Tabel 5. Tabel Nilai Kriteria Alternatif

\begin{tabular}{ccccccc}
\hline No & NRP Personel & C01 & C02 & C03 & C04 & C05 \\
\hline 1 & NRP001 & 4 & 4 & 4 & 3 & 3 \\
2 & NRP002 & 4 & 4 & 4 & 2 & 1 \\
3 & NRP003 & 3 & 4 & 3 & 3 & 3 \\
4 & NRP004 & 3 & 3 & 3 & 3 & 2 \\
\hline
\end{tabular}

Dari nilai kriteria alternatif pada Tabel 5, dilakukan proses penentuan nilai GAP dengan perbandingan nilai scoring dan nilai profil alternatif. Nilai perbedaan GAP dapat dilihat pada Tabel 6:

Tabel 6. Tabel Nilai Perbedaan GAP

\begin{tabular}{cccccc}
\hline NRP Personel & C01 & C02 & C03 & C04 & C05 \\
\hline NRP001 & 4 & 4 & 4 & 3 & 3 \\
NRP002 & 4 & 4 & 4 & 2 & 1 \\
NRP003 & 3 & 4 & 3 & 3 & 3 \\
NRP004 & 3 & 3 & 3 & 3 & 2 \\
\hline Nilai Scoring & 4 & 4 & 3 & 3 & 3 \\
\hline NRP001 & 0 & 0 & 1 & 0 & 0 \\
NRP002 & 0 & 0 & 1 & -1 & -2 \\
NRP003 & -1 & 0 & 0 & 0 & 0 \\
NRP004 & -1 & -1 & 0 & 0 & -1 \\
\hline
\end{tabular}

Setelah didapatkan nilai perbedaan GAP, maka dapat dilakukan proses perbandingan nilai GAP. Nilai perbandingan GAP berpedoman pada Tabel 2. Hasil dari perbandingan GAP dapat dilihat pada Tabel 7:

\begin{tabular}{cccccc} 
Tabel 7. Tabel Nilai Perbandingan GAP Alternatif \\
\hline NRP Personel & C01 & C02 & C03 & C04 & C05 \\
\hline NRP001 & 5 & 5 & 4,5 & 5 & 5 \\
NRP002 & 5 & 5 & 4,5 & 4 & 3 \\
NRP003 & 4 & 5 & 5 & 5 & 5 \\
NRP004 & 4 & 4 & 5 & 5 & 4 \\
\hline
\end{tabular}

Tahapan selanjutnya adalah menetapkan nilai Core Factor dan Second Factor dari hasil nilai perbandingan GAP yang diperoleh. Dengan rumus penentuan nilai Core Factor dan Second Factor, maka diperoleh hasil seperti pada Tabel 8:

Tabel 8. Tabel Nilai Core Factor dan Second Factor

\begin{tabular}{ccc}
\hline $\begin{array}{c}\text { NRP } \\
\text { Personel }\end{array}$ & $\begin{array}{c}\text { Core Factor } \\
\mathrm{NCF}=(\mathrm{C} 01+\mathrm{C} 02+\mathrm{C} 03) / 3\end{array}$ & $\begin{array}{c}\text { Second Factor } \\
\mathrm{NSF}=(\mathrm{C} 04+\mathrm{C} 05) / 2\end{array}$ \\
\hline NRP001 & 4,83 & 5,00 \\
NRP002 & 4,83 & 3,50 \\
NRP003 & 4,67 & 5,00 \\
NRP004 & 4,33 & 4,50 \\
\hline
\end{tabular}

Dari hasil Core Factor dan Second Factor, maka dapat diperoleh Nilai Kriteria Dasar. Persentase kepentingan untuk nilai Core Factor adalah sebesar $70 \%$ dan persentase kepentingaan Second Factor sebesar 30\%. Maka dengan rumus yang digunakan, didapatkan hasil Nilai Kriteria Dasar seperti pada Tabel 9:

Tabel 9. Tabel Hasil Nilai Kriteria Dasar

\begin{tabular}{cccc}
\hline $\begin{array}{c}\text { NRP } \\
\text { Personel }\end{array}$ & $\begin{array}{c}\text { Core Factor } \\
70 \% * \text { NCF }\end{array}$ & $\begin{array}{c}\text { Second Factor } \\
\text { 30\%*NSF }\end{array}$ & $\begin{array}{c}\text { Nilai Kriteria } \\
\text { Dasar }\end{array}$ \\
\hline NRP001 & 3,38 & 1,50 & 4,88 \\
NRP002 & 3,38 & 1,05 & 4,43 \\
NRP003 & 3,27 & 1,50 & 4,77 \\
NRP004 & 3,03 & 1,35 & 4,38 \\
\hline
\end{tabular}

Selanjutnya Nilai kriteria Dasar ini dapat dijadikan sebagai nilai utilitas pada metode MAUT.

Untuk proses selanjutnya adalah dengan menggunakan metode MAUT. Langkah awal dalam proses metode MAUT ini adalah menentukan nilai utilitas setiap kriteria pada alternatif. Nilai utilitas setiap alternatif dapat dilihat pada Tabel 10:

Tabel 10. Tabel Nilai Utilitas Alternatif

\begin{tabular}{llllll}
\hline NRP Personel & K01 & \multicolumn{1}{c}{ K02 } & \multicolumn{1}{c}{ K03 } & K04 & K05 \\
\hline NRP001 & 4,88 & 21 & 19,95 & 22,1 & 80 \\
NRP002 & 4,43 & 19,95 & 19,6 & 20,15 & 80 \\
NRP003 & 4,77 & 19,6 & 20,65 & 22,1 & 85 \\
NRP004 & 4,38 & 19,95 & 19,6 & 20,15 & 80 \\
\hline Bobot Relatif & 50 & 10 & 10 & 20 & 10 \\
\hline
\end{tabular}


Langkah selanjutnya adalah menentukan nilai normalisasi dari setiap nilai utilitas dan bobot relatif. Maka dengan menggunakan rumus, dapat diperoleh nilai normalisasi utilitas alternatif sebagai berikut :

a. Normalisasi Nilai Utilitas Kriteria K01

$$
\mathrm{xi}(\min )=4,38 \quad \mathrm{xi}(\max )=4,88
$$

$$
\begin{array}{ll}
\mathrm{A}_{11}=\frac{4,88-4,38}{4,88-4,38}=1 & \mathrm{~A}_{12}=\frac{4,43-4,38}{4,88-4,38}=0,1 \\
\mathrm{~A}_{13}=\frac{4,77-4,38}{4,88-4,38}=0,78 & \mathrm{~A}_{14}=\frac{4,38-4,38}{4,88-4,38}=0
\end{array}
$$

b. Normalisasi Nilai Utilitas Kriteria K02

$$
\begin{array}{ll}
\mathrm{xi}(\min )=19,6 & \mathrm{xi}(\max )=21 \\
\mathrm{~A}_{21}=\frac{21-19,6}{21-19,6}=1 & \mathrm{~A}_{22}=\frac{19,95-19,6}{21-19,6}=0,25 \\
\mathrm{~A}_{23}=\frac{19,6-19,6}{21-19,6}=0 & \mathrm{~A}_{24}=\frac{19,95-19,6}{211-19,6}=0,25
\end{array}
$$

c. Normalisasi Nilai Utilitas Kriteria K03

$$
\mathrm{xi}(\min )=19,6 \quad \mathrm{xi}(\max )=20,65
$$

$$
\begin{array}{ll}
\mathrm{A}_{31}=\frac{19,95-19,6}{20,65-19,6}=0,33 & \mathrm{~A}_{32}=\frac{19,6-19,6}{20,65-19,6}=0 \\
\mathrm{~A}_{33}=\frac{20,65-19,6}{20,65-19,6}=1 & \mathrm{~A}_{34}=\frac{19,6-19,6}{20,65-19,6}=0
\end{array}
$$

d. Normalisasi Nilai Utilitas Kriteria K04

$$
\operatorname{xi}(\min )=20,15 \quad x i(\max )=22,1
$$

$$
\begin{array}{ll}
\mathrm{A}_{41}=\frac{222_{1} 1-20,15}{222_{1} 1-20,15}=1 & \mathrm{~A}_{42}=\frac{20,15-20,15}{222_{\Perp} 1-20,15}=0 \\
\mathrm{~A}_{43}=\frac{22,1-20,15}{222_{1} 1-20,15}=1 & \mathrm{~A}_{44}=\frac{20,15-20,15}{222_{\Perp} 1-20,15}=0
\end{array}
$$

e. Normalisasi Nilai Utilitas Kriteria K05

$$
\begin{array}{lc}
\mathrm{xi}(\min )=80 & \mathrm{xi}(\max )=85 \\
\mathrm{~A}_{51}=\frac{80-80}{85-80}=0 & \mathrm{~A}_{52}=\frac{80-80}{85-80}=0 \\
\mathrm{~A}_{53}=\frac{85-80}{85-80}=1 & \mathrm{~A}_{54}=\frac{80-80}{85-80}=0
\end{array}
$$

Selanjutnya lakukan normalisasi terhadap nilai bobot relatif sebagai berikut :

a. Normalisasi Bobot Nilai Kriteria Dasar

$$
\mathrm{W}_{1}=\frac{50}{\{50+10+10+20+10)}=0,5
$$

b. Normalisasi Bobot Nilai Generik Pejabat

$$
\mathrm{W}_{2}=\frac{10}{(50+10+10+20+10)}=0,1
$$

c. Normalisasi Bobot Nilai Generik Rekan Kerja

$$
\mathrm{W}_{3}=\frac{10}{(50+10+10+20+10)}=0,1
$$

d. Normalisasi Bobot Nilai Spesifik

$$
\mathrm{W}_{4}=\frac{20}{(50+10+10+20+10)}=0,2
$$

e. Normalisasi Bobot Nilai Psikotest

$$
\mathrm{W}_{5}=\frac{10}{(50+10+10+20+10)}=0,1
$$

Maka dari proses tersebut, dapat diperoleh nilai Total Normalisasi. Nilai Total Normalisasi diperoleh dari perkalian nilai normalisasi utilitas dan normalisasi bobot relatif. Hasil nilai total normalisasi dilihat pada Tabel 11:

Tabel 11. Tabel Nilai Total Normalisasi

\begin{tabular}{cccccc}
\hline NRP Personel & K01 & K02 & K03 & K04 & K05 \\
\hline NRP001 & 0,5 & 0,1 & 0,03 & 0,2 & 0 \\
NRP002 & 0,05 & 0,02 & 0 & 0 & 0 \\
NRP003 & 0,39 & 0 & 0,1 & 0,2 & 0,1 \\
NRP004 & 0 & 0,02 & 0 & 0 & 0 \\
\hline
\end{tabular}

Selanjutnya untuk mendapatkan nilai evaluasi total adalah menjumlah nilai setiap kriteria pada masing-masing alternatif. Nilai evaluasi total diperoleh seperti pada Tabel 12:

Tabel 12. Tabel Nilai Evaluasi Total

\begin{tabular}{ccc}
\hline NRP Personel & Nilai Evaluasi Total & Rangking \\
\cline { 1 - 3 } NRP001 & 0,833 & 1 \\
NRP002 & 0,075 & 3 \\
NRP003 & 0,790 & 2 \\
NRP004 & 0,025 & 4 \\
\hline
\end{tabular}

Maka dari nilai evaluasi total tersebut, dapat dijadikan sebagai bahan keputusan, dimana nilai evaluasi total tertinggi dapat dijadikan saran keputusan terbaik. Pada Tabel 12 diperoleh nilai tertinggi sebesar 0,833 dengan NRP Personel yaitu NRP001 yang dapat dijadikan keputusan terbaik dalam penentuan mutasi jabatan.

\section{Kesimpulan}

Berdasarkan pembahasan yang telah dilakukan, maka dapat ditarik kesimpulan dan saran sebagai berikut :

\section{Simpulan}

Metode Profile Matching dan MAUT telah dapat melakukan analisa kriteria penilaian setiap personel yang mengajukan mutasi jabatan, sehingga menghasilkan nilai evaluasi total yang dapat dijadikan saran keputusan terbaik. Dari hasil yang diperoleh, dihasilkan nilai tertinggi sebesar 83,3\%, pada sebuah alternatif sehingga alternatif tersebut telah dapat dijadikan sebagai bahan pertimbangan dalam keputusan.

\section{Saran}

Untuk penelitian selanjutnya, dapat dilakukan pengembangan terhadap kriteria penilaian yang lebih kompleks dan penggunaan metode lain yang dapat menghasilkan nilai yang lebih baik lagi. 


\section{Daftar Pustaka}

[1] Ejimabo, N. O., 2015. The Influence of Decision Making in Organization Leadership and Management Activities. Journal of Entepreneur \& Organization Management, 4 (2), 1-13, doi: 10.4172/2169-026x.1000138.

[2] Z Tharo Z. dan Siahaan P. A., 2016. Profile Matching in Solving Rank Problem. IOSR Journal of Humanities and Social Sciences, 19 (3), 1-41, DOI:10.9790/2834-1105017376

[3] Oktopanda, 2017. A Study Approach of Decision Support System with Profile Matching. International Journal of Recent Trends in Engineering \& Research, 3(2), 3144, doi= 10.23883/IJRTER.2017.3001.ZL93N.

[4] Majumdar, Shrivastava A. K., Kapur P. K. dan Khatri K., 2017. Release And Testing Stop Time Of a Software using Multi_atribute Utility Theory. Society for Reliability and Safety, doi=10.10077/s41872.017.0005.9.

[5] Sari N., 2016. Sistem Penentuan Mutasi Pegawai Berdasarkan Metode Multifactor Evaluation Process. BILTEK, 4(18), 19041633.

[6] Hidayat R., 2016. Menentukan Promosi Jabatan Karyawan Dengan Menggunakan Metode Profile dan Metode Promethee. Indoneesian Journal on Software Engineering, 2(1), 57-65, 2461-0690.

[7] Buksh Z.A.,Stipanovic I., Klanker G., Connor A.O. dan Doree A.G., 2018. Network Level Brigades Maintenance Planning Using MultiAttribute Utility Theory. Structure And
Infrastructure Engineering, 1573-2479, doi = 10.1080/15732479.2017.1414858.

[8] Jannah R. dan Lusiana, 2015 Aplikasi Penerimaan Karyawan dengan Metode Multi Attribute Utility Theory. Sains dan Teknologi Informasi, 1(2), 77-89.

[9] Kusuma C., 2017. Analisis Program Restrukturisasi Kredit Macet Perbankan Dengan Menggunakan Metode Multi Atribute Utility Theory dan Vooting Copeland Score. Jurnal Ilmu Komputer dan Bisnis, 8 (1), 52348058.

[10] B Hariyanto R. M. dan Maslihah, 2017. Sistem Pendukung Keputusan Seleksi Pemilihan Kepala Bagian Perum Damri Surabaya. Information Technologi Jurnal, 3 (2), 35-40, 2442-3386.

[11] Sabri A., 2013. Kebijakan dan Pengambilan Keputusan Dalam Lembaga Pendidikan Islam. Jurnal Al-Ta'lim, 1(5), 373-379, doi=10. 15548/jt.v20i2.34.

[12] Magdalena H., 2012. Sistem Pendukung Kuputusan untuk menentukan Mahasiswa Lulusan Terbaik Di Perguruan Tinggi. Seminar Nasional Teknologi Informasi dan Komunikasi, 49-56,2089-9815.

[13] Ahmadi, Defit, S. Dan Na'am, J., 2018 Aplikasi Penerimaan Karyawan dengan Metode Multi Attribute Utility Theory. Rekayasa Sistem dan Teknologi Informasi, 2(2), 452-457, 2580-0760. doi: 10.29207/resti.v2i2.358

[14] Velasquez M. dan Hester P.T., 2013. An Analysis of Multi-Criteria Decision Making Methods. International Jornal of Operations Research, 10(2), 2304-9693. 